\title{
Jean-Marie Seillan, Huysmans, politique et religion
}

\section{Ida Merello}

\section{(2) OpenEdition}

\section{Journals}

\section{Edizione digitale}

URL: http://journals.openedition.org/studifrancesi/6997

DOI: 10.4000/studifrancesi.6997

ISSN: 2427-5856

\section{Editore}

Rosenberg \& Sellier

\section{Edizione cartacea}

Data di pubblicazione: 1 septembre 2010

Paginazione: 397

ISSN: 0039-2944

\section{Notizia bibliografica digitale}

Ida Merello, «Jean-Marie Seillan, Huysmans, politique et religion», Studi Francesi [Online], 161 (LIV | II) |

2010, online dal 30 novembre 2015, consultato il 13 janvier 2021. URL: http://

journals.openedition.org/studifrancesi/6997 ; DOI: https://doi.org/10.4000/studifrancesi.6997

\section{Questo documento è stato generato automaticamente il 13 janvier 2021.}

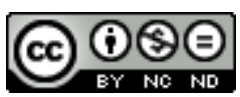

Studi Francesi è distribuita con Licenza Creative Commons Attribuzione - Non commerciale - Non opere derivate 4.0 Internazionale. 


\title{
Jean-Marie Seillan, Huysmans, politique et religion
}

\author{
Ida Merello
}

\section{NOTIZIA}

JEAN MARIE SEILLAN, Huysmans, politique et religion, Paris, Classiques Garnier, 2009, pp. 440.

1 L'A. affronta l'evoluzione dell'atteggiamento politico e religioso di Huysmans che si realizza tra il 1884 e il 1893, mostrando come anche nell'iniziale anarchismo, fondato su premesse di sinistra, fossero prevalenti il rifiuto della modernità (dagli aspetti tecnologici a quelli estetici, dallo scambio mercantile alle rivendicazioni femminili), l'antimilitarismo, il sarcasmo non solo nei confronti della "mystique du peuple", ma anche dei partiti al governo, come tanti segnali della successiva metamorfosi. L'A. identifica nell'opera En rade il momento in cui il pensiero di Huysmans si mette in movimento, con la contrapposizione di un idillico passato a un mondo presente, il non senso contemporaneo al senso e all'ordine espressi dall'epoca medievale. L'A. propone quindi una serrata riflessione sugli elementi costitutivi della visione del mondo dello scrittore, sulla base non solo della produzione letteraria, ma anche di tutto l'apparato testuale che la circonda (prefazioni, diari, saggi, interviste: un peritesto insomma nella sua concezione più estesa) offrendone una messa in prospettiva per molti versi inedita che comporta una nuova sistemazione critica. Ad esempio è convinzione dell'A. che Huysmans non riprenda più il personaggio di Durtal dopo L'Oblat perché non può più costituire il suo doppio funzionale, la disparità essendo sempre maggiore. 